\title{
TEACHER'S ROLES IN PHYSICAL EDUCATION
}

\author{
Nemanja Jeremić ${ }^{1}$, Ivana Milanović ${ }^{2}$, Snežana Radisavljević-Janić ${ }^{2}$ Dušanka Lazarević ${ }^{2}$ \\ ${ }^{1}$ University of Belgrade, Facultu of Sport and Physical Education, MAS, Serbia \\ ${ }^{2}$ University of Belgrade, Facultu of Sport and Physical Education, Serbia
}

\begin{abstract}
The roles of PE teachers in the teaching process are numerous, complex and varied. The aim of this research was to examine the opinion of students and PE teachers about the importance of the roles of teachers in the teaching process. Theopinions were examined in regard to gender and type of school attendedfor the students, and gender and length of service for the teachers. Additionally, the research aimed at determining whether the students' and PE teachers' opinions and evaluations differ with regard to the importance of some roles of teachers. The sample of respondents consisted of 368 students of the third and fourth grade of four secondary schools and $75 \mathrm{PE}$ teachers from the territory of the city of Belgrade. The Questionnaire for the examination of students' and teachers' opinions on the roles of PE teachers in the teaching process was applied in this research (Lukač, 2016). The obtained results showed that students, and especially teachers, highly value all roles of teachers. Students consider The role as a partner in affective interaction as the most important one. In the students' opinion regarding gender, there is a significant differencein the evaluation of The role as a partner in affective interaction, which was considered more important by the female students. In regard to gender and lenght of service, teachers did not show any differences in opinion on the importance of the roles of teachers. Teachers, in relation to students, evaluate all roles of teachers as more important. The results of this research are important for designing professional development of teachers and improving the teaching process.
\end{abstract}

Key words: PHYSICAL EDUCATION TEACHER / TEACHING EXPERIENCE / TEACHER'S ROLES /

\section{INTRODUCTION}

Education as a complex system with a clear organization and the school as its segment determine the position from which the role of teacher in the teaching process arises (Havelka, 2000). According to many authors, the teacher has a central place in the realization of the teaching process, considering his numerous and varied activities related to teaching contents and their realization, as well as all activities of importance for quality interaction with students in the teaching process (Avramović and Vujačić, 2010; Bakovljev, 1988; Darling-Hammond, 2006; Janjušević, 1967). Taking into account the diversity, the number and realization of these activities in the totality of the educational process, the role of teachers can be determined at the same time as composite and unique (Havelka, 2000). This role is composite because it always consists of several groups of mandatory and expected activities. However, it is also unique in so far as all the groups of included activities have a clear internal balance with regard to the orientation of these activities towards achieving educational goals and creating the optimal pedagogical situation through which the teacher encourages and directs students' behaviour. The position of teacher in the teaching process includes numerous, diverse, complex, interdependent roles that require energy investment, endurance, good concentration, emotional stability, and mental integrity of the personality. They can be: prescribed, normative, classical, historically present and those related to the realization of educational and professional work (Danilović, 2011). The following roles are recognized as some of the most important: lecturer (methodologist), instruction organizer, partner in communication, expert, motivator, evaluator, regulator of social relations, affective interactions, cognitive-diagnostic and others. The 
success of the teaching itself, as well as the quality of an individual class, depends on the way in which the teacher performs these roles (Avramović and Vujačić, 2010). There are different classifications of the roles of teachers in the teaching process (Havelka, 2000; Lindgren, 1976;). The starting point in this paper was the classification of the roles by Ivić and associates (2001), which is directed, first of all, to the roles that are expressed in the interaction of teachers and students in educational process that is in line with the modern tendency of active learning (Tudor, 1993). This approach to learning in the teaching process assumes the cooperation of teachers and students in the building of new knowledge and their complementary activities. These authors state that, despite the fact that certain roles of teachers in teaching practice overlap, they can be clearly distinguished and separated from one another, and accordingly suggest the following classification: the teaching role (teacher as a lecturer, instruction organizer, expert); motivational role (as it encourages cognitive hunger among students and motivates them to work); the role of the evaluator (rating in the domain of knowledge and of student's behaviour and personality); cognitive-diagnostic role (to recognize individual differences as well as to know the characteristics of students); the role of regulator of social relations in the class as a group (influence on the social climate in the classroom, solving conflicts among students) and the role as a partner in affective interaction (knowing the student's affective conditions, taking actions to help a child) (Ivić, Pešikan and Antić, 2001).

An overview of previous research suggests that students and teachers believe that roles of the teachers are realized at a certain level, but not all to the same extent (Avramović and Vujačić, 2010; Bjekić 2000; Ilić, 2007). Both groups value the expertise of teacher, but also the positive personality traits, such as: fairness, accessibility, openness etc. (Ilić and Stević, 1996; Petrović-Bjekić, 2000; Radovanović, 1989; Radovanović, 1994; Radovanović, Arunović, Madić and Višnjić, 1993; Sorgić, 1991). Also, students highly appreciate the teachers who establish a relationship with them based on trust and mutual respect, and accordingly they consider the role of a partner in affective interaction as the most needed one (Lukač, 2016).

Physical education occupies a significant place in the educational system. It is an integral part of institutionalized education, as well as of the efforts of an individual to improve and progress with his own activity, in accordance with current norms and values, as well as personal and social needs, whereby this subject is not different from other subjects (Višnjić, Jovanović and Miletić, 2004). However, there are some specificities in which physical education differs from other subjects. Classes are conducted in a special ambiance with lots of equipment and props, and fundamental tool in teaching is a physical exercise. There is increased responsibility of the teacher to reduce the degree of potential risk of students' injuries (Visnjic et al., 2004; Shimon, 2011). Also, the increased interaction among students, as well as the interaction between teachers and students is an opportunity to get to know the teacher psychological and physical characteristics of students. The results of the research on students' motivation in physical education also point to the important role of teachers for the quality involvement of students in PE classes (Cox \& Williams, 2008). Due to these specificities, and in accordance with the previously stated attitude that the success of the teaching depends on the way in which the teacher performs his roles in the teaching process, it is necessary to examine in more detail the roles of PE teachers.

The aim of the research was to examine the opinions of students and PE teachers about the importance of the roles of teachers in the teaching process of physical education. The opinions were examined in regard to gender and type of school attended for the students, and gender and length of service for the teachers. The purpose of the research was also to determine the possible differences in opinions and evaluations of the importance of individual roles of teachers between students and PE teachers. 


\section{METHOD}

\section{Sample of respondents}

The sample of respondents in this study consisted of two sub-samples. The first sub-sample consisted of 368 students (140 male and 228 female) of the third and fourth grade of four secondary schools from the territory of the city of Belgrade (Zemun and Twelfth High School, Medical School „Beograd” and Technical School „Tehnoart”), age $(M=17.42, S D=0.73)$. The second sub-sample was made up of $75 \mathrm{PE}$ teachers (40 male and 35 female) from the territory of the city of Belgrade. A non-probability sampling method was used, a convenience sample.

\section{Variables}

Independent variables in this research were students' gender and the type of school they attend, and gender and length of service for PE teachers, while the dependent variables were the roles of teachers (Teaching role, Motivational role, The role of the evaluator, Cognitive-diagnostic role, The role of regulator of social relations in the class as a group and The role as a partner in affective interaction).

\section{Instrument}

The research included the Questionnaire for the examination of students' and teachers' opinions on the roles ofPE teachers in the teaching process (Lukač, 2016). The questionnaire contains 64 items grouped into six subscales: Teaching role, Motivational role, The role of the evaluator, Cognitive-diagnostic role, The role of regulator of social relations in the class as a group and The role as a partner in affective interaction). The items were measured by the five-point Likert-type scale in which students and teachers assessed the extent to which the activities related to the items are necessary in the behaviour of teachers in the teaching process as part of the roles of teachers $(1=$ not necessary at all, $2=$ not necessary, $3=$ usually necessary, $4=$ necessary and $5=$ very necessary).

\section{Procedure}

Students were interviewed during the second half of May of the school year 2016/2017. in the classes of physical education (at the Zemun High School and Technical School „Tehnoart”), as well as the classes of other subjects (Twelfth Belgrade High School and Medical School „Beograd”). Prior to completing the questionnaire, students received a brief instructions and it was stressed that the interviewing was anonymous and on a voluntary basis.

PE teachers were interviewed also in the same schools where the students were interviewed, but most of the teacher sub-sample was interviewed during a seminar held at the "Summer school of pedagogues in physical education", held from 25-27 August 2017. Part of the teachers filled out the questionnaires electronically.

\section{Data analysis}

The basic descriptive statistics was used for analysing the obtained data, and from the domain of comparative statistics, a one-way MANOVA was used. Cronbach's alpha coefficient was used to check the internal consistency for each of the subscales of the Questionnaire for the examination of students' and teachers' opinions on the roles of PE teachers in the teaching process.

\section{RESULTS}

Reliability check (internal consistency) of the subscales of the Questionnaire for the examination of students' and teachers' opinions on the roles of $\mathrm{PE}$ teachers in the teaching process for the student subsample showed a high internal consistency (Crobnach's a ranges from .92 to .96). Also, for a teacher sub-sample, the internal consistency for each of the subscales is satisfactory (Crobnach's a ranges from .74 to .83 )

The results of descriptive statistics on the student sub-sample, observed for each role of teachers are shown in Table 1 . The obtained mean values range from 3.72 to 4.07 . 
Jeremić N., et. al., Teacher's Roles in Physical Education..., PHYSICAL CULTURE 2018; 72 (2): 191-201

Table 1. Basic descriptive parameters of students' opinions on the roles of teachers $(N=368)$

\begin{tabular}{lllll}
\hline Roles of teachers & Min & Max & M & SD \\
\hline Teaching role & 1.50 & 5.00 & 3.87 & 0.58 \\
Motivational role & 1.00 & 5.00 & 3.94 & 0.73 \\
The role of the evaluator & 1.43 & 5.00 & 4.04 & 0.66 \\
Cognitive-diagnostic role & 1.00 & 5.00 & 4.00 & 0.72 \\
The role of regulator of social relations in the class as a group & 1.00 & 5.00 & 3.72 & 0.81 \\
The role as a partner in affective interaction & 1.33 & 4.89 & 4.07 & 0.61 \\
\hline
\end{tabular}

Annotation: $N$-number of respondents; Min- minimal value; $M a x$ - maximal value; $M$ - arithmetic mean;

$S D$ - standard deviation.

For the purpose of determining the existence of differences in opinions and evaluations of the roles of $\mathrm{PE}$ teachers among students in relation to gender, a multivariate analysis of variance (MANOVA) was used, which showed that there was a statistically sig- nificant effect of gender $(\mathrm{F}(2,368)=3.05, \mathrm{p}=0.00$, Hotelling's $=.051, \eta 2=0.05$ ), i.e. there are differences between male and female students in assessing the roles of PE teachers (Table 2).

Table 2. Basic descriptive parameters for student sub-sample and differences in regard to gender (one-way MANOVA)

\begin{tabular}{|c|c|c|c|c|c|c|c|}
\hline Roles of teachers & & Min & $\operatorname{Max}$ & $\mathbf{M}$ & SD & $\mathbf{p}$ & $\eta^{2}$ \\
\hline Teaching role & $\begin{array}{l}\text { Male } \\
\text { Female }\end{array}$ & $\begin{array}{l}1.50 \\
2.58\end{array}$ & $\begin{array}{l}5.00 \\
5.00\end{array}$ & $\begin{array}{l}3.83 \\
3.91\end{array}$ & $\begin{array}{l}0.67 \\
0.53\end{array}$ & 0.21 & 0.00 \\
\hline Motivational role & $\begin{array}{l}\text { Male } \\
\text { Female }\end{array}$ & $\begin{array}{l}1.00 \\
1.67\end{array}$ & $\begin{array}{l}5.00 \\
5.00\end{array}$ & $\begin{array}{l}3.88 \\
3.99\end{array}$ & $\begin{array}{l}0.84 \\
0.65\end{array}$ & 0.17 & 0.00 \\
\hline The role of the evaluator & $\begin{array}{l}\text { Male } \\
\text { Female }\end{array}$ & $\begin{array}{l}2.43 \\
1.43\end{array}$ & $\begin{array}{l}5.00 \\
5.00\end{array}$ & $\begin{array}{l}3.98 \\
4.08\end{array}$ & $\begin{array}{l}0.67 \\
0.65\end{array}$ & 0.17 & 0.00 \\
\hline Cognitive-diagnostic role & $\begin{array}{l}\text { Male } \\
\text { Female }\end{array}$ & $\begin{array}{l}1.17 \\
1.00\end{array}$ & $\begin{array}{l}5.00 \\
5.00\end{array}$ & $\begin{array}{l}3.95 \\
4.03\end{array}$ & $\begin{array}{l}0.75 \\
0.71\end{array}$ & 0.30 & 0.00 \\
\hline $\begin{array}{l}\text { The role of regulator of social } \\
\text { relations in the class as a } \\
\text { group }\end{array}$ & $\begin{array}{l}\text { Male } \\
\text { Female }\end{array}$ & $\begin{array}{l}1.00 \\
1.00\end{array}$ & $\begin{array}{l}5.00 \\
5.00\end{array}$ & $\begin{array}{l}3.75 \\
3.71\end{array}$ & $\begin{array}{l}0.84 \\
0.80\end{array}$ & 0.65 & 0.00 \\
\hline $\begin{array}{l}\text { The role as a partner in } \\
\text { affective interaction }\end{array}$ & $\begin{array}{l}\text { Male } \\
\text { Female }\end{array}$ & $\begin{array}{l}1.89 \\
1.33\end{array}$ & $\begin{array}{l}4.89 \\
4.89\end{array}$ & $\begin{array}{l}3.95 \\
4.14\end{array}$ & $\begin{array}{l}0.66 \\
0.58\end{array}$ & 0.00 & 0.02 \\
\hline
\end{tabular}

Annotation: $N$-number of respondents; Min- minimal value; Max- maximal value; $M$ - arithmetic mean; $S D$ - standard deviation; $p$ - statistical significance; $\eta^{2}$ - effect size.

MANOVA was used to determine the existence of differences in the observation and evaluation of the roles of teachers in regard to the type of attended school and showed that there was a statistically significant effect of the type of school $(\mathrm{F}(3,368)=1.989, \mathrm{p}$
$=.023$, Hotelling's $=.066, \eta 2=0.03$ ), i.e. there are differences between students attending different types of schools in assessing the roles of PE teachers (Table 3). Based on the post hoc Bonferroni test $(\mathrm{p}=.043)$ it has been established that students who attend Tech- 
nical school are significantly different in observing and evaluating Motivation role in relation to students attending High and Medical schools.

Table 3. Basic descriptive parameters for student sub-sample in regard to type of school they attend and one-way MANOVA.

\begin{tabular}{|c|c|c|c|c|c|c|c|}
\hline Roles of teachers & & Min & $\operatorname{Max}$ & $\mathbf{M}$ & SD & $\mathbf{p}$ & $\eta^{2}$ \\
\hline \multirow{3}{*}{ Teaching role } & High School & 1.50 & 5.00 & 3.85 & 0.63 & \multirow{3}{*}{0.12} & \multirow{3}{*}{0.01} \\
\hline & Medical & 2.67 & 5.00 & 3.98 & 0.54 & & \\
\hline & Technical & 2.67 & 5.00 & 3.80 & 0.51 & & \\
\hline \multirow{3}{*}{ Motivational role } & High School & 1.00 & 5.00 & 3.98 & 0.72 & \multirow{3}{*}{0.03} & \multirow{3}{*}{0.01} \\
\hline & Medical & 1.17 & 5.00 & 4.03 & 0.77 & & \\
\hline & Technical & 2.00 & 5.00 & 3.75 & 0.65 & & \\
\hline \multirow{3}{*}{ The role of the evaluator } & High School & 1.43 & 5.00 & 3.99 & 0.67 & \multirow{3}{*}{0.17} & \multirow{3}{*}{0.00} \\
\hline & Medical & 2.43 & 5.00 & 4.13 & 0.63 & & \\
\hline & Technical & 1.86 & 5.00 & 4.06 & 0.66 & & \\
\hline \multirow{3}{*}{ Cognitive-diagnostic role } & High School & 1.50 & 5.00 & 3.99 & 0.70 & \multirow{3}{*}{0.95} & \multirow{3}{*}{0.00} \\
\hline & Medical & 1.00 & 5.00 & 4.01 & 0.74 & & \\
\hline & Technical & 1.17 & 5.00 & 4.01 & 0.78 & & \\
\hline \multirow{3}{*}{$\begin{array}{l}\text { The role of regulator of social relations } \\
\text { in the class as a group }\end{array}$} & High School & 1.33 & 5.00 & 3.69 & 0.85 & \multirow{3}{*}{0.58} & \multirow{3}{*}{0.00} \\
\hline & Medical & 1.00 & 5.00 & 3.79 & 0.88 & & \\
\hline & Technical & 2.33 & 5.00 & 3.74 & 0.61 & & \\
\hline \multirow{3}{*}{$\begin{array}{l}\text { The role as a partner in affective } \\
\text { interaction }\end{array}$} & High School & 1.44 & 4.89 & 4.01 & 0.65 & \multirow{3}{*}{0.15} & \multirow{3}{*}{0.01} \\
\hline & Medical & 1.33 & 4.89 & 4.14 & 0.62 & & \\
\hline & Technical & 2.44 & 4.89 & 4.14 & 0.49 & & \\
\hline
\end{tabular}

Annotation: $N$-number of respondents; Min- minimal value; Max- maximal value; $M$ - arithmetic mean; $S D$ - standard deviation; $p$ - statistical significance; $\eta^{2}$ - effect size.

The results of descriptive statistics on the teacher sub-sample, observed for each of the roles of teachers

are shown in Table 4. The obtained mean values range from 4.38 to 4.49 .

Table 4. Basic descriptive parameters for teacher sub-sample

\begin{tabular}{|c|c|c|c|c|c|}
\hline Roles of teachers & $\mathbf{N}$ & Min & $\operatorname{Max}$ & $\mathbf{M}$ & SD \\
\hline Teaching role & 75 & 1.08 & 5.00 & 4.42 & 0.75 \\
\hline Motivational role & 75 & 1.00 & 5.00 & 4.38 & 0.74 \\
\hline The role of the evaluator & 75 & 1.00 & 5.00 & 4.47 & 0.73 \\
\hline Cognitive-diagnostic role & 75 & 1.00 & 5.00 & 4.38 & 0.74 \\
\hline $\begin{array}{l}\text { The role of regulator of social relations in the class as a } \\
\text { group }\end{array}$ & 75 & 1.00 & 5.00 & 4.39 & 0.77 \\
\hline The role as a partner in affective interaction & 75 & 1.00 & 5.00 & 4.49 & 0.75 \\
\hline
\end{tabular}

Annotation: $N$-number of respondents; Min- minimal value; Max- maximal value; $M$ - arithmetic mean; SD- standard deviation. 
MANOVA showed that there is no statistically significant effect of gender $(\mathrm{F}(2.75)=1.139, \mathrm{p}=.349$, Hotelling's $=.101, \eta 2=.091$ ), i.e. there are no differences between male and female teachers in assessing the roles of PE teachers. Also, there is no statistically significant effect of the factor of length of service $(F$ $(4.75)=.848, \mathrm{p}=.642$, Hotelling's $=.236, \eta 2=.073)$, i.e. there are no differences between teachers in assessing the roles of PE teachers in relation to lenght of service.
Differences in the perception and evaluation of the roles of teachers between students and teachers were also checked by MANOVA. The results showed that there is a statistically significant effect of the status (student/teacher) $(\mathrm{F}(2,443)=9.887, \mathrm{p}=.000$, Hotelling's $=.136, \eta 2=0.12$ ), i.e. there are differences between students and teachers in assessing the roles of PE teachers (Table 5).

Table 5. Basic descriptive parameters for student and teacher sub-samples and differences between them (MANOVA)

\begin{tabular}{|c|c|c|c|c|c|c|c|c|}
\hline Roles of teachers & Status & $\mathbf{N}$ & Min & $\operatorname{Max}$ & $\mathbf{M}$ & SD & $\mathbf{p}$ & $\eta^{2}$ \\
\hline Teaching role & $\begin{array}{l}\text { Students } \\
\text { Teachers }\end{array}$ & $\begin{array}{c}368 \\
75\end{array}$ & $\begin{array}{l}1.50 \\
1.08\end{array}$ & $\begin{array}{l}5.00 \\
5.00\end{array}$ & $\begin{array}{l}3.87 \\
4.42\end{array}$ & $\begin{array}{l}0.58 \\
0.75\end{array}$ & 0.00 & 0.10 \\
\hline Motivational role & $\begin{array}{l}\text { Students } \\
\text { Teachers }\end{array}$ & $\begin{array}{c}368 \\
75\end{array}$ & $\begin{array}{l}1.00 \\
1.00\end{array}$ & $\begin{array}{l}5.00 \\
5.00\end{array}$ & $\begin{array}{l}3.95 \\
4.38\end{array}$ & $\begin{array}{l}0.73 \\
0.74\end{array}$ & 0.00 & 0.04 \\
\hline The role of the evaluator & $\begin{array}{l}\text { Students } \\
\text { Teachers }\end{array}$ & $\begin{array}{c}368 \\
75\end{array}$ & $\begin{array}{l}1.43 \\
1.00\end{array}$ & $\begin{array}{l}5.00 \\
5.00\end{array}$ & $\begin{array}{l}4.04 \\
4.47\end{array}$ & $\begin{array}{l}0.66 \\
0.73\end{array}$ & 0.00 & 0.05 \\
\hline $\begin{array}{l}\text { Cognitive-diagnostic } \\
\text { role }\end{array}$ & $\begin{array}{l}\text { Students } \\
\text { Teachers }\end{array}$ & $\begin{array}{c}368 \\
75\end{array}$ & $\begin{array}{l}1.00 \\
1.00\end{array}$ & $\begin{array}{l}5.00 \\
5.00\end{array}$ & $\begin{array}{l}4.00 \\
4.34\end{array}$ & $\begin{array}{l}0.72 \\
0.93\end{array}$ & 0.00 & 0.03 \\
\hline $\begin{array}{l}\text { The role of regulator of } \\
\text { social relations in the } \\
\text { class as a group }\end{array}$ & $\begin{array}{l}\text { Students } \\
\text { Teachers }\end{array}$ & $\begin{array}{c}368 \\
75\end{array}$ & $\begin{array}{l}1.00 \\
1.00\end{array}$ & $\begin{array}{l}5.00 \\
5.00\end{array}$ & $\begin{array}{l}3.72 \\
4.39\end{array}$ & $\begin{array}{l}0.81 \\
0.77\end{array}$ & 0.00 & 0.08 \\
\hline $\begin{array}{l}\text { The role as a partner in } \\
\text { affective interaction }\end{array}$ & $\begin{array}{l}\text { Students } \\
\text { Teachers }\end{array}$ & $\begin{array}{c}368 \\
75\end{array}$ & $\begin{array}{l}1.33 \\
1.00\end{array}$ & $\begin{array}{l}4.89 \\
5.00\end{array}$ & $\begin{array}{l}4.07 \\
4.49\end{array}$ & $\begin{array}{l}0.61 \\
0.75\end{array}$ & 0.00 & 0.05 \\
\hline
\end{tabular}

Annotation: $N$-number of respondents; $M i n$ - minimal value; $M a x$ - maximal value; $M$-arithmetic mean; $S D$ - standard deviation; $p$ - statistical significance; $\eta^{2}$ - effect size.

\section{DISCUSSION}

The results obtained in this research dedicated to the roles of teachers in physical education indicate that students highly value all evaluated roles of teachers. However, they consider The role as a partner in affective interaction as the most significant one, and as the least important they value The role of regulator of social relations in the class as a group. The results obtained are very similar to the results obtained by Lukač (2016). It is important to emphasize that students do not consider any of the evaluated roles of teachers irrelevant, since even The role of regulator of social relations in the class as a group, which the students see as the least important, has a mean value that indicates high degree of importance of this role (Table 1).As part of this role, the students evaluated as the least important those items related to teachers' mediation in resolving conflicts among students, as well as the need for a teacher to talk to students about their problems. Such results may be considered to be somewhat expected, given the characteristics of the developmental period of the 3 -grade and 4-grade students, whose opinion was examined in this research. Explaining the motive for autonomy and freedom, Rot (2003) states that in the period of puberty and adolescence the sensitivity to ordering and the tendency to maintain their own autonomy are particularly pronounced, which often leads to conflict be- 
tween children and parents or another person who expresses authoritative behaviour toward them. As a result, it can be concluded that young people at this age consider themselves independent and adult enough to solve their own problems, and that any attempt of interference by the adults, to some extent, is considered an attack on their personality.

As somewhat less important than the other roles, besides The role of the regulator of social relations in the class as a group, students have evaluated the Teaching role. Within this role, the lowest evaluated items were: to prepare for the class, to organize/ arrange students well for work in class and to constantly improve himself. Interestingly, of all the items in the questionnaire students considered the least needed the one that claims that a PE teacher should prepare himself for the class. These data lead to the conclusion that students do not attach importance to the organization of the class. A review of some previous studies that dealt with similar issues points to the contradiction of the results, which relate to this role of PE teachers. The results obtained in this study are not in compliance with the research carried out by a group of authors (Radovanović, et al.,1993), which shows that students believe that a PE teacher should be a good organizer of classes. Similar results were obtained by Ilić and Stević (1996), whose research showed that female students of the third grade of secondary school, when it comes to the traits of PE teachers in teaching process, put the ability to organize teaching well in the first place. Krnjajić (2002) summarized the research results obtained by several national authors which indicate that teachers are expected to teach in an understandable and interesting way, to know their subject well, to work with the whole class, to explain tasks readily and answer students' questions. There are also studies that support the results obtained in this research. Thus, Radovanovic's (1989) research shows that less than half of the interviewed male students and only one third of the female students consider that is necessary for a PE teacher to possess professional knowledge. The research carried out by Lukač (2016) also showed similar results. Namely, out of the six evaluated roles, the students put the role that refers to teacher as the expert for his field and organizer of teaching process in the fifth place. These differences in the results obtained from some of the previous studies points to the need for conducting further research on this topic.
As already mentioned, students see The role as a partner in affective interaction as the most important role of $\mathrm{PE}$ teachers in the teaching process. Students evaluate the majority of items in this group very high. First of all, this means that the teacher does not insult the students, not to make fun of them, to appreciate the students and their work, and to know how to keep the privacy of the students. These results are in line with numerous studies conducted so far. Sorgić (1991) found that students regard accessibility and pleasantness the most desirable traits of a teacher. In his research, Radovanović (1994) found that students value the most honesty, objectivity, sense of humor, positivity and natural behaviour of a teacher.

Krnjajić (2002) refers to one of Jersild's most widely quoted studies (1940) on student preferences in various forms of teacher behaviour, in which it is found that students prefer teachers who possess the following traits: kindness, thoughtfulness, accessibility, cheerfulness, naturalness, sociability, good mood and sense of joke. However, it is interesting to note that students evaluated two items related to this role with significantly lower grades. These are: to recognize students' feelings and their needs and to help students overcome their problems (by conversation, by cooperation with parents and psychologist). This can be explained by a sensitive age of the students of senior grades of secondary school, as well as their selfperception and the need for autonomy. In addition, on the basis of the students' low evaluation of the listed items, we can conclude that they are not ready to open enough and trust teachers, hoping that they will get help in overcoming some negative feelings, problems and affective states. The reason for this may lie in the belief that adolescents are more likely to share their problems, needs, and emotional states with some of their close peers than with parents, coaches or in this case teachers. Rot (2003) speaks of „peer culture”, by which he implies behavioural standards set by a particular youth group. These standards are often in conflict with the perceptions and norms of parents and other adults. He further states that peers in childhood, and particularly in adolescence strongly affect the personalityformation and that, according to many authors, this influence goes beyond the influence of teachers.

As a very important role the students also see The role of the evaluator. The items that are most valued are those that relate to the requirement for a teacher to 
be equal to everyone, to explain a grade and to evaluate the progress of each student individually for the given exercise. These results are expected, given that most of the previous studies have shown that students with their teachers value impartiality and objectivity. Sorgić (1991) has come to the conclusion that students as a very desirable feature of teacher, when it comes to teacher's attitude towards students, assessed the item of having equal treatment for all students. Research by Radovanović (1994) and Ilić and Stević (1996) also showed that students greatly appreciated the teacher's objectivity in evaluation.

Observed by gender, there was a significant difference in the evaluation of The role as a partner in affective interaction, which was evaluated as more important by the female students. Lukač (2016), who came to similar results, sees the cause for these differences in the interpretation of Janjetović (1996) who thinks that the expressed emotionality of young men has a negative social and individual connotation and that it is more related to the female stereotype, while male stereotype implies its opposite, i.e. rationality.

In relation to the type of school they attend, students differ only in the observation and evaluation of Motivation role. Based on the Bonferroni post hoc test, it has been found that students attending Technical school are significantly different from those attending High school and Medical school in perceiving and evaluating the Motivation role, which they consider to be less important. Although the students of the Technical school value the Motivational role as the least important and accordingly differ significantly from the students of the other two schools, it must be emphasized that they also value this role highly (Table 3).

Each of the six evaluated roles of teachers was valued very highly by $\mathrm{PE}$ teachers. Teachers, like students, perceive The role as a partner in affective interaction as somewhat more important. The evidence to the extent to which teachers evaluate positively all the evaluated roles of teachers is the fact that even the least valued role, the Motivational role, has a high mean value, indicating a high degree of valuing this role (Table 4). These results are to some extent consistent with the results of the research published by Avramović and Vujačić (2010). The research carried out by these authors, as well as the results of the research that is the subject of this paper, indicate that teachers have a formed image of how an ideal teacher should behave, what personality traits he should possess, and what roles he should perform and to what extent. The problem is reflected in the data that the authors also mentioned, which indicate that teachers, although they are aware of the qualities that a teacher should possess and how they should behave in interaction with students during the teaching process, do not apply this knowledge in practice to the extent necessary.

Both male and female teachers, regardless of their length of service, have highly evaluated each of the roles. These data are in line with the results obtained by Korać and Sladojević Matić (2014), who indicate that teachers'gender as well as the length of service, do not play an important role in assessing the importance of the roles of teachers. On the other hand, a research conducted by Vujačić (2008) shows that there are some differences in the perception and evaluation of certain aspects of teaching process between teachers in relation to their length of service. These differences are most striking with the item related to the preparation of teachers for the class. Namely, young teachers prepare more and more thoroughly for classes, while the older ones rely more on educational and pedagogical experience. This author concludes that with years of work experience there is a decline in teachers' interest in preparing for the class. The obtained results should be checked in a research involving a larger sample of teachers.

Teachers, contrary to students, evaluate all roles of teachers as significantly important. These results are in line with the results of the research conducted by Korać and Sladojević Matić (2014). Although the sample of respondents in that research were fine arts teachers, most of the assessed competences referred to teaching in general, so it is possible to draw a parallel between the two studies. The reason for these differences should be sought in the fact that teaching, both $\mathrm{PE}$ and teaching in general, is a very complex process, and that students do not have a sufficiently developed awareness of the procedures that need to be implemented in order to effectively and fully realize this process. This is also supported by the previously stated information, that the students, as the least important of all the items in the questionnaire, assessed the one that claims that the teacher should prepare himself for the class. As less important students evaluated items related to organizing students in class, as well as the need for the teacher to con- 
stantly improve himself. Knowing how much the basic preparation and good organization of a class is important for the realization of the objectives and tasks of the teaching process, and to what extent the constant professional development of teachers is necessary, it can be concluded that students cannot understand and perceive in the right way certain aspects of a teaching process, which is understandable since the process of their education is still ongoing. In addition, it should be kept in mind that the subject of the students' and teachers' evaluation in this paper examined the roles of PE teachers in the teaching process, and accordingly it is expected that teachers will have a more positive opinion on issues concerning their profession in relation to students. Throughout the education for the chosen occupation, teachers develop positive attitudes and opinions about their profession. This is confirmed to a certain extent with the research conducted by Kovačević (2013), aimed to show how students of the fourth year of the Faculty of Sport and Physical Education in Belgrade evaluate the competencies of teachers. It is necessary to point out the interesting data obtained by Avramović and Vujačić (2010), based on the examination of teachers' opinions on how students see them. Namely, the teachers think that the students would evaluate them very positively, first of all when it comes to communicating with students and preparing for the class. It is interesting that in this research, the two items were, roughly speaking, evaluated as less important by the students.

\section{CONCLUSION}

Based on the results obtained in this study, the main goal of which was to examine the opinions of students and PE teachers about the importance of the roles of teachers in the teaching process of physical education, it is possible to make several conclusions. Students and teachers highly value all assessed roles of teachers in the PE teaching process, with the teachers giving more significant values to all roles. Both students and teachers see The role as a partner in affective interaction as the most necessary role of teacher. The compliance among students in terms of gender in evaluating the roles of teachers is evident, and the only difference manifested with The role as a partner in affective interaction, which female students value more than male students. Both male and female students see The role of the regulator of social relations in the class as a group as the least important one. Compared to the type of school the students attend, the only difference is in the perception and evaluation of the Motivational role, to which the students of the Technical school give less importance. In relation to gender and length of service of teachers, no differences in opinion about the importance of the roles of teachers have been expressed.

A PE teacher should possess professional knowledge and skills, as well as certain desirable personality traits, which will enable him to be a key factor in the process of student development.This research provides an insight into what roles of teachers are considered more important than the others by students and teachers themselves. This can be a guideline that will indicate the direction of future professional development of PE teachers. Future research should include a larger sample of both students and PE teachers, and examine the factors that play a significant role in evaluating the roles of teachers.

\section{Acknowlegements}

This paper is the result of the projects: „Improving the quality and accessibility of education in modernization processes in Serbia" No 47008 (2011-2014) and the project „The effects of physical activity application to locomotor, metabolic, psychosocial and educational status with population of the Republic of Serbia“ No III47015 (2011-2014) financially supported by the Ministry of Education and Science of the Republic of Serbia 


\section{REFERENCES}

1. Avramović, 3. \& Vujačić, M. (2010). Nastavnik izmedu teorije i prakse. [A teacher between theory and practice. In Serbian]. Beograd: Institut za pedagoška istraživanja.

2. Bakovljev, M. (1988). Didaktika. [Didactics. In Serbian]. Beograd: Naučna knjiga.

3. Bjekić, D. (2000). Kako učenici procenjuju ostvarivanje uloga nastavnika. [How students assess the role of teachers. In Serbian]. Nastava i vaspitanje 49(5), 707-724.

4. Cox, A. \& Williams, L. (2008). The roles of perceived teacher support, motivational climate, and psychological need satisfaction in students' physical education motivation. Journal of sport and exercise psychology, 30(2), 222-239.

5. Danilović, M. (2011). Nastavnik kao uzor, model, idol, ideal, simbol, vrednost, tj. mera savršenog i svestrano obrazovanog čoveka. [Teacher as a model, model, idol, ideal, symbol, value, i.e. the measure of a perfect and versatile educated man. In Serbian]. Zbornik radova sa 6. Medunarodnog simpozijuma Tehnologija, informatika $i$ obrazovanje za društvo učenja i znanja (str. 3-25). Čačak: Tehnički fakultet.

6. Darling-Hammond, L. (2006). Constructing 21 st-century teacher education. Journal of teacher education, 57(3), 300-314.

7. Havelka, N. (2000). Učenik i nastavnik u obrazovnom procesu. [A student and teacher in the educational process. In Serbian]. Beograd, Zavod za udžbenike i nastavna sredstva.

8. Ilić, D. \& Stević, S. (1996). Mišljenje sedamnaestogodišnjih učenica o profesoru fizičkog vaspitanja. [The opinion of seventeen year old students about the teacher of physical education. In Serbian]. Fizička kultura 50(4), 306-311.

9. Ilić, S. (2007). Mišljenje učenika, roditelja i profesora fizičkog vaspitanja o nastavničkim kompetencijama. [Opinion of students, parents and professors of physical education about teachers' competences. In Serbian]. Beograd. Fakultet sporta i fizičkog vaspitanja.

10. Ivić, I., Pešikan, A. \& Antić, S. (2001). Aktivno učenje.[Active learning. In Serbian]. Beograd: Institut za psihologiju.
11. Janjušević, M. (1967). Didaktika. [Didactics, In Serbian]. Beograd: Vuk Karadžić.

12. Korać, I. \& Sladojević-Matić, J. (2014). Kompetencije nastavnika - perspektiva nastavnika i učenika. [Teacher competences - the perspective of teachers and students. In Serbian]. Zbornik radova Učiteljskog fakulteta, Užice 17(16), 235-248.

13. Kovačević, I. (2013). Procena nastavničkih kompetencija od strane studenata Fakulteta sporta $i$ fizičkog vaspitanja [Assessment of teacher competencies by students of the Faculty of Sport and Physical Education. In Serbian]. Beograd. Fakultet sporta i fizičkog vaspitanja.

14. Krnjajić, S. (2002). Socijalni odnosi i obrazovanje. [Social relations and education. In Serbian]. Beograd: Institut za pedagoška istraživanja; Vršac: Viša škola za obrazovanje vaspitača.

15. Lindgren, H. (1976). Educational Psychology in the Classroom. NewYork: John Wiley\&Sons Inc.

16. Lukač, B. (2016). Ispitivanje mišljenja učenika o ulogama nastavnika fizičkog vaspitanja $u$ nastavnom procesu. [Examining students' opinions about the role of teachers in physical education in the teaching process . In serbian]. Fakultet sporta i fizičkog vaspitanja, Beograd.

17. Petrović-Bjekić, D. (2000). Uspešnost u nastavi i empatija nastavnika. [Teacher performance and empathy . In Serbian]. Psihologija 33(3-4), 499-520.

18. Radovanović, Đ. (1989). Stavovi učenika prema osobinama nastavnika fizičkog vaspitanja. [Student attitudes toward to the characteristics of teachers of physical education. In Serbian]. Fizička kultura 43(1-2), 53-58.

19. Radovanović, Đ., Arunović, D., Madić, B., i Višnjić, D. (1993). Stavovi učenika srednjih škola u Srbiji prema osobinama nastavnika fizičkog vaspitanja. [Attitudes of secondary school students in Serbia according to the characteristics of teachers of physical education. In Serbian]. Fizička kultura 47(1-2), 10-13.

20. Radovanović, I. (1994). Stavovi učenika prema osobinama nastavnika fizičkog vaspitanja.[Student attitudes according to the characteristics of teachers of physical education. In Serbian]. Fizička kultura 48(3), 223-228. 
21. Rot, N. (2003). Osnovi socijalne psihologije. [Basics of Social Psychology. In Serbian]. Beograd, Zavod za udžbenike i nastavna sredstva.

22. Shimon, J. M. (2011). Introduction to teaching physical education: Principles and strategies. Human Kinetics.

23. Sorgić, G. (1991). Poželjne i nepoželjne osobine nastavnika fizičkog vaspitanja iz učeničkog ugla. [Preferred and undesirable characteristics of teachers of physical education from the pupil's angle. In Serbian]. Fakultet fizičke kulture, Novi Sad.
24. Tudor, I. (1993). Teacher roles in the learner-centred classroom. ELT journal, 47(1), 22-31.

25. Višnjić, D., Jovanović, A. \& Miletić, K. (2004). Teorija $i$ metodika fizičkog vaspitanja. [Theory and Methodics of Physical Education. In Serbian]. Beograd: Fakultet sporta i fizičkog vaspitanja.

26. Vujačić, M. (2008). Kako nastavnici vide sami sebe. [How teachers see themselves. In Serbian] Nastava i vaspitanje, 57(2), 230-241.

\title{
ROLES DE PROFESORES EN EDUCACIÓN FÍSICA
}

\begin{abstract}
Extracto
Los papeles de los profesores de educación física en el proceso de enseñanza son numerosos, complejos y diversos. El objetivo de la investigación era investigar la opinión de los alumnos y de los profesores de educación física sobre la importancia del papel de profesor en el proceso de enseñanza. La opinión se investigó en relación con el sexo y el tipo de escuela que acuden, es decir el sexo y los años de trabajo de los profesores. La investigación, también, tenía por objetivo establecer también si existen diferencias en la opinión y la valoración de la importancia de algunos papeles de los profesores entre los alumnos y los profesores de educación física. La muestra de los examinados ha sido compuesta de los 368 alumnos de tercer y cuarto grado de cuatro escuelas secundarias y de los 75 profesores de educación física del territorio de la ciudad de Belgrado. En la investigación se aplicó el Cuestionario para investigar la opinión de alumnos y profesores sobre la importancia del papel de los profesores de educación física en el proceso de enseñanza. Los resultados obtenidos demostraron que los alumnos, y sobre todo profesores, valoran altamente todos los papeles de los profesores. Los alumnos consideran como el más importante el "Papel de socios en la interacción afectiva". En la opinión de los alumnos por el sexo, aparecieron diferencias significativas en la valoración del "Papel de socios en la interacción afectiva", que las alumnas consideran algo más importante en relación con los alumnos. En relación con el sexo y los años de trabajo de los profesores, no se mostraron diferencias en la opinión sobre la importancia del papel de los profesores. Los profesores en relación con los alumnos, valoran todos los papeles de profesores mucho más importantes. Los resultados de esta investigación tienen importancia en la concepción del perfeccionamiento profesional de los profesores y en la promoción del proceso de enseñanza.
\end{abstract}

Palabras claves: PROFESOR DE EDUCACIÓN FÍSICA / EXPERIENCIA DE LOS PROFESORES / ROLES DE PROFESORES

Received: 25.07.2018.

Accepted: 15.12.2018. 


\title{
УЛОГЕ НАСТАВНИКА У ФИЗИЧКОМ ВАСПИТАҢУ
}

\author{
Немања Јеремић $^{1}$, Ивана Милановић ${ }^{2}$, Снежана Радисављевић Јанић ${ }^{2}$, Душанка Лазаревић ${ }^{2}$ \\ ${ }^{1}$ Универзитет у Београду, Факултет спорта и физичког васпитања, МАС \\ ${ }^{2}$ Универзитет у Београду, Факултет спорта и физичког васпитања
}

\begin{abstract}
Сажетак
Улоге наставника физичког васпитања у наставном процесу су бројне, комплексне и разноврсне. Циљ истраживања је био да се испита мишљење ученика и наставника физичког васпитања о важности улога наставника у наставном процесу. Мишљење је испитивано у односу на пол и врсту школе коју похађају ученици, односно пол и године радног стажа наставника. Такође, истраживање је имало за циљ да утврди и да ли постоје разлике у мишљењу и вредновању важности појединих улога наставника између ученика и наставника физичког васпитања. Узорак испитаника чинило је 368 ученика трећег и четвртог разреда четири средње школе и 75 наставника физичког васпитања са територије града Београда. У истраживању је примењен Упитник за испитивање мишљења ученика и наставника о важности улога наставника физичког васпитања у наставном процесу (Лукач, 2016). Добијени резултати су показали да ученици, а посебно наставници, високо вреднују све наставничке улоге. Ученици најзначајнијом сматрају Улогу партнера у афективној интеракцији. У мишљењу ученика према полу појавила се значајна разлика у вредновању Улоге партнера у афективној интеракцији, коју ученице сматрају нешто важнијом у односу на ученике. У односу на пол и радни стаж наставника нису се испољиле разлике у мишљењу о важности наставничких улога. Наставници у односу на ученике све наставничке улоге вреднују значајно важнијим. Резултати овог истраживања имају значај у конципирању професионалног усавршавања наставника и унапређења наставног процеса.
\end{abstract}

КљУчне речи: НАСТАВНИК ФИЗИЧКОГ ВАСПИТАҢА / НАСТАВНИЧКО ИСКУСТВО / НАСТАВНИЧКЕ УЛОГЕ

\section{УВОД}

Образовање као сложен систем са јасном организацијом и школа као његов сегмент одређују положај из којег проистиче улога наставника у наставном процесу (Хавелка, 2000). Према многим ауторима наставник има централно место у реализацији наставног процеса, с обзиром на његове бројне и разноврсне активности везано за наставне садржаје и њихову реализацију, као и све активности од значаја за квалитетну интеракцију са ученицима у наставном процесу (Аврамовић и Вујачић, 2010; Баковљев, 1988; Darling-Hammond, 2006; Јањушевић, 1967). Када се има у виду разноврсност, бројност и реализација ових активности уукупностиобразовногпроцеса, улога наставника се може одредити као истовремено композитна и јединствена (Хавелка, 2000).Та улога је композитна јер се увек састоји из више група обавезних и очекиваних активности.Улога наставника је јединствена у смислу да између свих група активности које она укључује постоји јасна унутрашња равнотежа у погледу усмерености тих активности на постизање васпитно-образових циљева и на стварање опималне педагошке ситуације преко које наставник подстиче и усмерава понашање ученика. Положај наставника у наставном процесу укључује бројне, разноврсне, комплексне, међузависне улоге које захтевају улагање енергије, издржљивост, добру концентрацију, емоционалну стабилност, ментални интегритет личности. Оне могу бити: прописане, нормативне, класичне, историјски присутне и оне које се односе на реализацију васпитног и стручног рада (Даниловић, 2011). Као неке од најважнијих препознају се следеће улоге: предавач (методичар), организатор наставе, партнер у комуникацији, стручњак, 
мотиватор, оцењивач, регулатор социјалних односа, афективна интеракција, сазнајно-дијагностичка и др. Успешност саме наставе, као и квалитет појединачног часа, зависе од начина на који наставник обавља ове улоге (Аврамовић и Вујачић, 2010). Постоје различите класификације улога наставника у наставном процесу (Lindgren, 1976; Хавелка, 2000). У овом раду пошло се од класификације улога Ивића и сарадника (2001) која је усмерена, пре свега, на улоге које се испољавају у интеракцији наставника и ученика у образовно-васпитном процесу, што је у складу са савременом тенденцијом активног учења. Овакав приступ учењу у настави претпоставља сарадњу наставника и ученика у изградњи нових знања и њиховим активностима које се допуњују (Tudor, 1993).Ови аутори наводе да, упркос томе што се поједине улоге наставника у наставној пракси преклапају, могуће их је сасвим јасно разликовати и међусобно раздвојити, па у складу са тим предлажу следећу класификацију: наставничка улога (наставник као предавач, организатор наставе, стручњак); мотивациона улога (како подстиче радозналост код ученка, мотивише их за учење и подстиче формирање радних навика); улога процењивача, евалуатора (оцењивање у домену знања и оцењивање понашања и личности ученика); сазнајно-дијагностичка улога (да препозна индивидуалне разлике као и да познаје узрасне карактеристике ученика); улога регулатора социјалних односа у разреду као групи (утицај на социјалну климу у разреду, решавање конфликата међу ученицима) и улога партнера у афективној интеракцији (познавање афективних стања ученика, предузимање акција за помоћ детету) (Ивић, Пешикан и Антић, 2001).

Преглед досадашњих истраживања указује на то да ученици и наставници сматрају да се наставничке улоге реализују у одређеном степену, али не све у истом обиму (Аврамовић и Вујачић, 2010; Бјекић 2000; Илић, 2007). И једни и други вреднују стручност наставника, али и позитивне особине личности као што су: правичност, приступачност, отвореност и тако даље (Илић и Стевић, 1996; Петровић-Бјекић, 2000; Радовановић, 1989; Радовановић, 1994; Радовановић, Аруновић, Мадић и Вишњић,
1993; Соргић, 1991). Такође, ученици веома цене и наставнике који са њима успостављају однос заснован на поверењу и узајамном поштовању, па сходно томе као најпотребнију процењују улогу партнера у афективној интеракцији (Лукач, 2016).

Физичко васпитање заузима значајно место у систему образовања. Оно је саставни део институционализованог васпитања и образовања, као и напора појединца да се усавршава и напредује сопственом активношћу, а у складу са важећим нормама и вредностима, као и личним и друштвеним потребама, по чему се овај предмет не разликује од других предмета (Вишњић, Јовановић и Милетић, 2004). Међутим, има и неких специфичности по којима се физичко васпитање разликује у односу на остале предмете. Настава се спроводи у посебном амбијенту са мноштвом справа и реквизита, а основно средство на часу представља физичка вежба. Постоји повећана одговорност наставника како би се смањио степен могућег ризика за повређивање ученика (Вишњић и cap., 2004; Shimon, 2011).Такође, повећана је и интеракција међу ученицима, као и интеракција између наставника и ученика што даје могућност наставнику да боље упозна психолошке и физичке карактеристике ученика. Резултати истраживања о мотивацији ученика у физичком васпитању, такође указују на важну улогу наставника за квалитетно укључивање ученика у наставу (Cox \& Williams, 2008). Имајући у виду ове специфичности, а у складу са раније изнетим ставом да успешност наставе зависи од начина на који наставник обавља своје улоге у наставном процесу, неопходно је детаљније истражити улоге наставника у физичком васпитању

Циљ истраживања је био да се испита мишљење ученика и наставника физичког васпитања о важности улога наставникау наставном процесу, у настави физичког васпитања. Мишљење је испитивано у односу на пол и врсту школе коју похађају ученици, односно пол и године радног стажа наставника.Такође, истраживање је имало за циљ да утврди и да ли постоје разлике у мишљењу и вредновању важности појединих улога наставника између ученика и наставника физичког васпитања. 
Јеремић Н., и сар., Улоге наставника у физичком васпитању..., ФИЗИЧКА КУЛТУРА 2018; 72 (2): 189-199

\section{МЕТОД}

\section{Узорак испитаника}

Узорак испитаника у овом истраживању су чинила два подузорка. Први подузорак је чинило 368 ученика (140 ученика и 228 ученица) трећег и четвртог разреда четири средње школе са територије града Београда (Земунска и Дванаеста београдска гимназија, Медицинска школа „Београд“ и Техничка школа „Техноарт“), узраста $(\mathrm{M}=17.42, S D=0.73)$. Други подузорак је чинило 75 наставника физичког васпитања (40 наставника и 35 наставница) са територије града Београда. Коришћена је невероватносна метода узорковања, пригодни узорак.

\section{Варијабле}

Независне варијабле у овом истраживању су пол ученика и врста школе коју похађају, пол и радни стаж наставника, а зависне варијабле су наставничке улоге (Наставничка улога, Мотивачиона улога, Улога проценивача, евалуатора, Сазнајно-дијагностичка улога, Улога регулатора соиијалних односа у разреду као групи и Улога партнера у афективној интеракиији).

\section{Инструмент}

У истраживању је примењен Упитник за испитивање мишљења ученика и наставника о улогама наставника физичког васпитања у наставном процесу (Лукач, 2016).Упитник садржи 64 ставке груписане у шест супскала: Наставничка улога, Мотивачиона улога, Улога проценивача, евалуатора, Сазнајно-дијагностичка улога, Улога регулатора соиијалних односа у разреду као групи и Улога партнера у абективној интеракиији. Ставке су праћене петостепеном скалом Ликертовог типа на којој су ученици и наставници процењивали колико су активности на које се ставке односе потребне у понашању наставника у наставном процесу у склопу наставничких улога (1=yопште није потребно, $2=$ није потребно, 3=углавном потребно, 4=nотребно и 5=веома потребно).

\section{Поступак}

Анкетирање ученика је спроведено током друге половине маја месеца школске 2016/2017. на часовима физичког васпитања (у Земунској гимназији и Техничкој школи „Техноарт“), као и на часовима других наставних предмета (Дванаеста београдска гимназија и Медицинска школа „Београд“). Пре попуњавања упитника ученици су добили кратко упутство за попуњавање, уз напомену да је анкетирање анонимно и на добровољној бази.

Анкетирање наставника физичког васпитања је спроведено у школама у којима су анкетирани ученици, док је већи део подузорка наставника анкетиран током семинара одржаног на „Летњој школи педагога физичке културе“, од 25.-27. августа 2017. Један део наставника је анкете попунио електронским путем.

\section{Анализа података}

За анализу добијених података примењена је основна дескриптивна статистика, а из домена компаративне статистике примењена је једнофакторска MANOVA. За проверу интерне конзистентности за сваку од супскала Упитика за испитивање мишљења ученика и наставника о улогама наставника физичког васпитања у наставном процесупримењен je Cronbah a коефицијент.

\section{РЕЗУЛТАТИ}

Провера поузданости (интерна конзистетност) супскалаУпитника за испитивање мишљења ученика и наставника о улогама наставника физичког васпитања у наставном процесу за подузорак ученика показала је високу интерну конзистентност (Cronbach a у распону од .92 до .96). Такође, и за подузорак наставника, интерна конзистентност за сваку од супскала je задовољавајућа (Cronbach a у распону од.74 до.83).

У Табели 1 приказани су резултати дескриптивне статистике на подузорку ученика, посматрано за сваку од улога наставника. Добијене средње вредности крећу се од 3.72 до 4.07 . 
Јеремић Н., и сар., Улоге наставника у физичком васпитању.., ФИЗИЧКА КУЛТУРА 2018; 72 (2): 189-199

Табела 1. Основни дескриптивни показатељи мишљења ученика о наставничким улогама (N=368)

\begin{tabular}{lcccc}
\hline Улоге наставника & Min & Max & M & SD \\
\hline Наставничка улога & 1.50 & 5.00 & 3.87 & 0.58 \\
Мотивациона улога & 1.00 & 5.00 & 3.94 & 0.73 \\
Улога процењивача, евалуатора & 1.43 & 5.00 & 4.04 & 0.66 \\
Сазнајно-дијагностичка улога & 1.00 & 5.00 & 4.00 & 0.72 \\
Улога регулатора социјалних односа у разреду као групи & 1.00 & 5.00 & 3.72 & 0.81 \\
Улога партнера у афективној интеракцији & 1.33 & 4.89 & 4.07 & 0.61
\end{tabular}

Легенда: $N$-број испитаника; Min-минимална вредност; Мax-максимална вредност; $M$-аритметичка средина; $S D$ - стандардна девијација.

У сврху утврђивања постојања разлика у мишљењу и вредновању улога наставника физичког васпитања међу ученицима у односу на пол коришћена је мултиваријатна анализа варијансе (MANOVA), која је показала да постоји статистички значајан ефекат пола $\left(F_{(2,368)}=3.05\right.$, $p=0.00$, Hotelling's $\left.=.051, \eta^{2}=0.05\right)$, односно да постоје разлике између ученика и ученица у процени улога наставника физичког васпитања (Табела 2).

Табела 2. Основни дескриптивни показатељи за подузорак ученика и разлике према полу (једнофакторска MANOVA))

\begin{tabular}{|c|c|c|c|c|c|c|c|}
\hline Улоге наставника & & Min & $\operatorname{Max}$ & $\mathbf{M}$ & SD & $\mathbf{p}$ & $\eta^{2}$ \\
\hline \multirow{2}{*}{ Наставничка улога } & Ученици & 1.50 & 5.00 & 3.83 & 0.67 & \multirow{2}{*}{0.21} & \multirow{2}{*}{0.00} \\
\hline & Ученице & 2.58 & 5.00 & 3.91 & 0.53 & & \\
\hline \multirow{2}{*}{ Мотивациона улога } & Ученици & 1.00 & 5.00 & 3.88 & 0.84 & \multirow{2}{*}{0.17} & \multirow{2}{*}{0.00} \\
\hline & Ученице & 1.67 & 5.00 & 3.99 & 0.65 & & \\
\hline \multirow{2}{*}{$\begin{array}{l}\text { Улога процењивача, } \\
\text { евалуатора }\end{array}$} & Ученици & 2.43 & 5.00 & 3.98 & 0.67 & \multirow{2}{*}{0.17} & \multirow{2}{*}{0.00} \\
\hline & Ученице & 1.43 & 5.00 & 4.08 & 0.65 & & \\
\hline \multirow{2}{*}{$\begin{array}{l}\text { Сазнајно-дијагностичка } \\
\text { улога }\end{array}$} & Ученици & 1.17 & 5.00 & 3.95 & 0.75 & \multirow{2}{*}{0.30} & \multirow{2}{*}{0.00} \\
\hline & Ученице & 1.00 & 5.00 & 4.03 & 0.71 & & \\
\hline \multirow{2}{*}{$\begin{array}{l}\text { Улога регулатора } \\
\text { социјалних односа у } \\
\text { разреду као групи }\end{array}$} & Ученици & 1.00 & 5.00 & 3.75 & 0.84 & \multirow{2}{*}{0.65} & \multirow{2}{*}{0.00} \\
\hline & Ученице & 1.00 & 5.00 & 3.71 & 0.80 & & \\
\hline \multirow{2}{*}{$\begin{array}{l}\text { Улога партнера у } \\
\text { афективној интеракцији }\end{array}$} & Ученици & 1.89 & 4.89 & 3.95 & 0.66 & \multirow{2}{*}{0.00} & \multirow{2}{*}{0.02} \\
\hline & Ученице & 1.33 & 4.89 & 4.14 & 0.58 & & \\
\hline
\end{tabular}

Легенда: $N$ - број испитаника; Min- минимална вредност; Мax- максимална вредност; $M$-аритметичка средина; $S D$ - стандардна девијација; р- статистичка значајност; $\eta^{2}-$ величина ефекта.

MANOVA је коришћена у циљу утврђивања постојања разлика у односу на врсту школе коју ученици похађају у опажању и вредновању улога наставника и показала је да постоји статистички значајан ефекат врста школе $\left(\mathrm{F}_{(3,368)}=1.989, p=.023\right.$,
Hotelling's $=.066, \eta^{2}=0.03$ ), односно да постоје разлике између ученика који похађају различите врсте школа у процени улога наставника физичког васпитања (Табела 3). На основу post hoc теста Bonferroni ( $\mathrm{p}=.043)$ утврђено је да се 
Јеремић Н., и сар., Улоге наставника у физичком васпитању..., ФИЗИЧКА КУЛТУРА 2018; 72 (2): 189-199

ученици који похађају Техничку школу значајно разликујуу опажању и вредновању Мотивационе улоге у односу на ученике који похађају Гимназију и Медицинску школу.

Табела 3. Основни дескриптивни показетељи за подузорак учениика према врсти школе коју похађају и једнофакторска MANOVA

\begin{tabular}{|c|c|c|c|c|c|c|c|}
\hline Улоге наставника & & Min & $\operatorname{Max}$ & $\mathbf{M}$ & SD & $\mathbf{p}$ & $\eta^{2}$ \\
\hline \multirow{3}{*}{ Наставничка улога } & Гимназија & 1.50 & 5.00 & 3.85 & 0.63 & \multirow{3}{*}{0.12} & \multirow{3}{*}{0.01} \\
\hline & Медицинска & 2.67 & 5.00 & 3.98 & 0.54 & & \\
\hline & Техничка & 2.67 & 5.00 & 3.80 & 0.51 & & \\
\hline \multirow{3}{*}{ Мотивациона улога } & Гимназија & 1.00 & 5.00 & 3.98 & 0.72 & \multirow{3}{*}{0.03} & \multirow{3}{*}{0.01} \\
\hline & Медицинска & 1.17 & 5.00 & 4.03 & 0.77 & & \\
\hline & Техничка & 2.00 & 5.00 & 3.75 & 0.65 & & \\
\hline \multirow{3}{*}{$\begin{array}{l}\text { Улога процењивача, } \\
\text { евалуатора }\end{array}$} & Гимназија & 1.43 & 5.00 & 3.99 & 0.67 & \multirow{3}{*}{0.17} & \multirow{3}{*}{0.00} \\
\hline & Медицинска & 2.43 & 5.00 & 4.13 & 0.63 & & \\
\hline & Техничка & 1.86 & 5.00 & 4.06 & 0.66 & & \\
\hline \multirow{3}{*}{$\begin{array}{l}\text { Сазнајно- } \\
\text { дијагностичка улога }\end{array}$} & Гимназија & 1.50 & 5.00 & 3.99 & 0.70 & \multirow{3}{*}{0.95} & \multirow{3}{*}{0.00} \\
\hline & Медицинска & 1.00 & 5.00 & 4.01 & 0.74 & & \\
\hline & Техничка & 1.17 & 5.00 & 4.01 & 0.78 & & \\
\hline \multirow{3}{*}{$\begin{array}{l}\text { Улога регулатора } \\
\text { социјалних односа у } \\
\text { разреду као групи }\end{array}$} & Гимназија & 1.33 & 5.00 & 3.69 & 0.85 & \multirow{3}{*}{0.58} & \multirow{3}{*}{0.00} \\
\hline & Медицинска & 1.00 & 5.00 & 3.79 & 0.88 & & \\
\hline & Техничка & 2.33 & 5.00 & 3.74 & 0.61 & & \\
\hline \multirow{3}{*}{$\begin{array}{l}\text { Улога партнера } \\
\text { у афективној } \\
\text { интеракцији }\end{array}$} & Гимназија & 1.44 & 4.89 & 4.01 & 0.65 & \multirow{3}{*}{0.15} & \multirow{3}{*}{0.01} \\
\hline & Медицинска & 1.33 & 4.89 & 4.14 & 0.62 & & \\
\hline & Техничка & 2.44 & 4.89 & 4.14 & 0.49 & & \\
\hline
\end{tabular}

Легенда:N- број испитаника; Min- минимална вредност; Мax- максимална вредност; $M$-аритметичка средина; $S D$ - стандардна девијација; р- статистичка значајност; $\eta^{2-}$ величина ефекта

У Табели 4 приказани су резултати дескриптивне статистике на подузорку наставника, посматрано за сваку од улога наставника.
Добијене средње вредности крећу се од 4.38 до 4.49 .

Табела 4. Основни дескриптивни показатељи за подузорак наставника

\begin{tabular}{|c|c|c|c|c|c|}
\hline Улоге наставника & $\mathbf{N}$ & Min & $\operatorname{Max}$ & $\mathbf{M}$ & SD \\
\hline Наставничка улога & 75 & 1.08 & 5.00 & 4.42 & 0.75 \\
\hline Мотивациона улога & 75 & 1.00 & 5.00 & 4.38 & 0.74 \\
\hline Улога процењивача, евалуатора & 75 & 1.00 & 5.00 & 4.47 & 0.73 \\
\hline Сазнајно-дијагностичка улога & 75 & 1.00 & 5.00 & 4.38 & 0.74 \\
\hline $\begin{array}{l}\text { Улога регулатора социјалних односа у разреду као } \\
\text { групи }\end{array}$ & 75 & 1.00 & 5.00 & 4.39 & 0.77 \\
\hline Улога партнера у афективној интеракцији & 75 & 1.00 & 5.00 & 4.49 & 0.75 \\
\hline
\end{tabular}

Легенда:N- број испитаника; Min- минимална вредност; Max- максимална вредност; $M$ - аритметичка средина; $S D$ - стандардна девијација. 
MANOVA је показала да не постоји статистички значајан ефекат пола $\left(F_{(2,75)}=1.139, p=.349\right.$, Hotelling's $\left.=.101, \eta^{2}=.091\right)$, односно да не постоје разлике између наставника и наставница у процени улога наставника физичког васпитања. Такође, не постоји статистички значајан ефекат фактора радни стаж $\left(F_{(4,75)}=.848, p=.642\right.$, Hotelling's $\left.=.236, \eta^{2}=.073\right)$, односно не постоје разлике између наставника и наставница у процени улога наставника физичког васпитања у односу на радни стаж.
Разликеу опажању и вредновању наставничких улога између ученика и наставника су такође провераване MANOVA анализом. Резултати су показали да постоји статистички значајан ефекат статуса испитаника (ученик/наставник) $\left(F_{(2,443)}=\right.$ 9.887, $p=.000$, Hotelling's $=.136, \eta^{2}=0.12$ ), односно да постоје разлике између ученика и наставника у процени улога наставника физичког васпитања (Табела 5).

Табела 5. Основни дескриптивни показатељи за подузорке ученика и наставника и разлике између њих (MANOVA)

\begin{tabular}{|c|c|c|c|c|c|c|c|c|}
\hline Улоге наставника & Статус & $\mathbf{N}$ & Min & $\operatorname{Max}$ & $\mathbf{M}$ & SD & $\mathbf{p}$ & $\eta^{2}$ \\
\hline \multirow{2}{*}{ Наставничка улога } & Ученици & 368 & 1.50 & 5.00 & 3.87 & 0.58 & \multirow{2}{*}{0.00} & \multirow{2}{*}{0.10} \\
\hline & Наставници & 75 & 1.08 & 5.00 & 4.42 & 0.75 & & \\
\hline \multirow{2}{*}{ Мотивациона улога } & Ученици & 368 & 1.00 & 5.00 & 3.95 & 0.73 & \multirow{2}{*}{0.00} & \multirow{2}{*}{0.04} \\
\hline & Наставници & 75 & 1.00 & 5.00 & 4.38 & 0.74 & & \\
\hline \multirow{2}{*}{$\begin{array}{l}\text { Улога процењивача, } \\
\text { евалуатора }\end{array}$} & Ученици & 368 & 1.43 & 5.00 & 4.04 & 0.66 & \multirow{2}{*}{0.00} & \multirow{2}{*}{0.05} \\
\hline & Наставници & 75 & 1.00 & 5.00 & 4.47 & 0.73 & & \\
\hline \multirow{2}{*}{$\begin{array}{l}\text { Сазнајно- } \\
\text { дијагностичка улога }\end{array}$} & Ученици & 368 & 1.00 & 5.00 & 4.00 & 0.72 & \multirow{2}{*}{0.00} & \multirow{2}{*}{0.03} \\
\hline & Наставници & 75 & 1.00 & 5.00 & 4.34 & 0.93 & & \\
\hline \multirow{2}{*}{$\begin{array}{l}\text { Улога регулатора } \\
\text { социјалних односа у } \\
\text { разреду као групи }\end{array}$} & Ученици & 368 & 1.00 & 5.00 & 3.72 & 0.81 & \multirow{2}{*}{0.00} & \multirow[b]{2}{*}{0.08} \\
\hline & Наставници & 75 & 1.00 & 5.00 & 4.39 & 0.77 & & \\
\hline \multirow{2}{*}{$\begin{array}{l}\text { Улога партнера } \\
\text { у афективној } \\
\text { интеракцији }\end{array}$} & Ученици & 368 & 1.33 & 4.89 & 4.07 & 0.61 & \multirow{2}{*}{0.00} & \multirow{2}{*}{0.05} \\
\hline & Наставници & 75 & 1.00 & 5.00 & 4.49 & 0.75 & & \\
\hline
\end{tabular}

Легенда: $N$ - број испитаника; Min- минимална вредност; Max- максимална вредност; $M$ - аритметичксредина; $S D$ - стандардна девијација; $p$ - статистичка значајност; $\eta^{2}-$ величина ефекта.

\section{ДИСКУСИЈА}

Резултати добијени у овом истраживању посвећеном улогама наставника у физичком васпитању указују на то да ученици високо вреднују све процењиване наставничке улоге. Ипак, најзначајнијом сматрају Улогу партнера у афективној интеракцији, а као најмање значајну вреднују Улогу регулатора социјалних односа у разреду као групи. Добијени резултати су веома слични резултатима до којих је дошла Лукач (2016). Важно је истаћи да ученици ниједну од процењиваних наставничких улога не сматрају неважном, пошто чак и Улога регулатора социјалних односа у разреду као групи, коју ученици виде као најмање важну, има средњу вредност која указује на висок степен важности ове улоге.У оквиру ове улоге, ученици су као најмање важне вредновали оне ставке које се тичу посредовања наставника у решавању конфликата међу ученицима, као и потребе да наставник разговара са ученицима о њиховим проблемима. Овакви резултати се донекле могу сматрати очекиваним, ако се у обзир узму карактеристике развојног периода у коме се налазе ученици трећег и четвртог разреда средње школе, чије је мишљење испитивано у овом истраживању. Објашњавајући мотив за самосталношћу и слободом, Рот (2003) наводи да су у периоду 
Јеремић Н., и сар., Улоге наставника у физичком васпитању..., ФИЗИЧКА КУЛТУРА 2018; 72 (2): 189-199

пубертета и адолесценције посебно изражени осетљивост на наређивање и тежња да се одржи властита самосталност, што често доводи до конфликта између деце и родитеља или неке друге особе која према њима испољава ауторитативно понашање. Може се закључити да млади у овом узрасту себе сматрају довољно самосталним и одраслим да сами решавају своје проблеме, и да сваки покушај мешања од стране одраслих, у одређеној мери, сматрају атаком на своју личност.

Ученици су као нешто мање важну у односу на остале улоге, поред Улоге регулатора социјалних односа у разреду као групи вредновали и Наставничку улогу. У оквиру ове улоге најниже су вредновали ставке: да се припрема за час, да добро организује/распоређује ученике за рад на часу и да се стално усавршава. Занимљив је податак да су ученици од свих ставки у упитнику као најмање потребну оценили ону која тврди да би наставник физичког васпитања требало да се припрема за час. Закључак који се може донети на основу ових података је да ученици не придају значај самој организацији часа. Осврт на нека претходна истраживања која су се бавила сличном проблематиком указује на контрадикторност резултата, који се односе на ову улогу наставника физичког васпитања. Резултати добијени у овом истраживању нису у сагласности са истраживањем које је спровела група аутора (Радовановић и сар. 1993) које показује да ученици сматрају да наставник физичког васпитања треба да буде добар организатор часова. До сличних резултата су дошли Илић и Стевић (1996), чије је истраживање показало да ученице трећег разреда средње школе, када је реч о особинама у раду наставника физичког васпитања, на прво место стављају способност доброг организовања наставе. Крњајић (2002) је сажео резултате истраживања више наших аутора који указују да се од наставника као предавача очекује да предаје на разумљив и занимљив начин, да добро познаје свој предмет, да ради са целим одељењем, да радо објашњава задатке и одговара на ученичка питања. Постоје и истраживања која поткрепљују резултате добијене у овом истраживању. Тако истраживање Радовановића (1989) показује да мање од половине анкетираних ученика и тек трећина ученица сматрају да је неопходно да наставник физичког васпитања поседује стручна знања. И истраживање које је спровела Лукач
(2016) је показало сличне резултате. Наиме, од шест процењиваних улога, ученици на претпоследње место стављају улогу која се односи на наставника као стручњака за своју област и организатора наставе. Ове разлике у резултатима неких од досадашњих истраживања указују на потребу за спровођењем даљих истраживања у овој области.

Као што је већ речено, ученици као најзначајнију улогу наставника физичког васпитања у наставном процесу видеУлогу партнера у афективној интеракцији. Највећи број ставки из ове групе ученици вреднују веома високо. Ту се пре свега мисли на то да наставник не вређа ученике, да им се не подсмева, да цени ученике и њихов рад, као и да зна да чува приватност ученика. Ови резултати су у складу са великим бројем досадашњих истраживања. Соргић (1991) је утврдио да ученици као најпожељније особине наставника виде приступачност и пријатност наставника. Истраживањем Радовановића (1994) је утврђено да ученици код наставника највише цене поштење, објективност, смисао за хумор, позитивност и природно понашање. Крњајић (2002) се позива на једну од најчешће цитираних студија Јерсилда (1940) о ученичким преференцијама различитих облика понашања наставника, у којој је утврђено да ученици више воле наставнике који поседују следећа својства: љубазност, пажљивост, приступачност, веселост, природност, друштвеност, добро расположење и смисао за шалу. Међутим, занимљив је податак да су ученици знатно нижим оценама вредновали две ставке које се односе на ову улогу. То су: да препознаје ученичка осећања и њихове потребе и да помаже ученицима у превазилажењу њихових проблема (разговором, сарадњом са родитељима и психологом). Ово се може објаснити осетљивим узрастом у коме се ученици старијих разреда средње школе налазе, као и њиховом самоперцепцијом и потребом за самосталношћу. Поред тога, на основу ниског вредновања наведених ставки од стране ученика, можемо закључити да они нису спремни да се у довољној мери отворе и поверенаставницима у нади да ће добити помоћ у превазилажењу неких негативних осећања, проблема и афективних стања. Разлог томе, можда лежи у веровању да су адолесценти склонији да своје проблеме, потребе и емоционална стања поделе са неким 
од себи блиских вршњака, него са родитељима, тренерима или у овом случају наставницима. Рот (2003) говори о „култури вршњака“, под чиме подразумева стандарде понашања које поставља одређена омладинска група. Ти стандарди су често у супротности са схватањима и нормама родитеља и других одраслих људи. Он даље наводи да вршњаци у детињству и пре свега младалачком добу имају велики утицај на формирање личности и да, по многим ауторима, тај утицај превазилази утицај наставника.

Ученици као веома важну виде и Улогу процењивача, евалуатора. Ставке коју су највише вредноване су оне које се односе на захтев да наставник приликом оцењивања буде једнак према свима, да образлаже оцену као и да у оцењивању узима у обзир напредак сваког ученика понаособ за дату вежбу. Ови резултати су и очекивани, с обзиром на то да је највећи број досадашњих истраживања показао да ученици код својих наставника вреднују непристрасност и објективност. Соргић (1991) је дошао до податка да су ученици као веома пожељну особину наставника, када је реч о односу наставника према ученицима, оценили ставку да има једнак однос према свим ученицима. Истраживања Радовановића (1994) и Илића и Стевића (1996) су такође показала да ученици веома цене објективност наставника приликом оцењивања.

Посматрано према полу ученика појавила се значајна разлика у вредновању Улоге партнера у афективној интеракцији, коју ученицесматрају нешто важнијом у односу на ученике. До сличних резултата је дошла и Лукач (2016) која узрок ових разлика види у тумачењу Јањетовића (1996) који сматра да изражена емоционалност код младића има негативну друштвену и индивидуалну конотацију и да је она атрибут који се у већој мери везује за женски стереотип, док мушки подразумева његову супротност, односно рационалност.

У односу на врсту школе коју похађају, ученици сеједино значајно разликују у опажању и вредновању Мотивационе улоге. На основу post hoc теста Bonferroni, утврђено је да се ученици који похађају Техничку школу значајно разликују у односу на ученике који похађају Гимназију и Медицинску школу у опажању и вредновању Мотивационе улоге, и то тако што је сматрају мање важном. Иако ученици Техничке школе најмање вреднују Мотивациону улогу и по томе се значајно разликују од ученика друге две школе, ипак се мора нагласити да и они високо вреднују ову улогу.

Свака од шест процењиваних улога наставника је вреднована веома високо од стране наставника физичког васпитања. И наставници, попут ученика, као нешто важнију виде Улогу партнера у афективној интеракцији. О томе у којој мери наставници позитивно вреднују све процењиване улоге наставника сведочи и податак да чак и најслабије вреднована улога, Мотивациона улога, има високу средњу вредност,која указује на висок степен вредновања ове улоге.Ови резултати су у одређеној мери у складу са резултатима истраживања које су објавили Аврамовић и Вујачић (2010). Истраживање које су спровели ови аутори, као и резултати истраживања које је предмет овог рада, указују на то да наставник има формирану слику о томе како би идеални наставник требало да се понаша, које особине личности да поседује, као и које би улоге требало да остварује и у којој мери. Проблем се огледа у подацима до којих су такође дошли поменути аутори, а који указују на то да наставници, и поред тога што су свесни квалитета које би наставник требало да поседује и како би требало да се понаша у интеракцији са ученицима током наставног процеса, не примењују та знања у пракси у потребној мери.

И наставници и наставнице су, без обзира на године радног стажа, веома високо оценили сваку од улога. Ови подаци су у складу са резултатима до којих су дошле Кораћ и Сладојевић Матић (2014), а који указују да пол наставника, као ни године радног стажа, не играју битну улогу у процењивању значаја наставничких улога. С друге стране, истраживање које је спровела Вујачић (2008), показује да постоје одређене разлике у опажању и вредновању појединих аспеката наставе између наставника у односу на године радног стажа. Ове разлике су најуочљивије код ставке која се односи на припрему наставника за час. Наиме, млађи наставници се више и темељније припремају за наставу, док се старији више ослањају на просветно-педагошко искуство. Ова ауторка изводи закључак да са годинама радног стажа опада заинтересованост за припремање часа код наставника. Провера 
Јеремић Н., и сар., Улоге наставника у физичком васпитању..., ФИЗИЧКА КУЛТУРА 2018; 72 (2): $189-199$

добијених резултата претпоставља истраживање које би обухватило већи узорак наставника.

Наставници у односу на ученике све наставничке улоге вреднују значајно важнијим. Ови резултати су у складу са резултатима истраживања које су спровеле Кораћ и Сладојевић Матић (2014). Иако су узорак испитаника у овом истраживању чинили наставници ликовне културе, већина процењиваних компетенција се тиче наставе уопште, тако да је могуће повући паралелу између ова два истраживања. Разлог овим разликама треба тражити у чињеници да настава, како настава физичког васпитања тако и настава уопште, представља један веома сложен процес и да ученици немају у довољној мери развијену свест о поступцима које је потребно предузети како би се тај процес ефикасно и у целости реализовао. Томе у прилог говори и раније изнет податак, да су ученици као најмање важну од свих ставки у упитнику проценили ону која тврди да наставник треба да се припрема за час. Као мање важне ученици су вредновали и ставке које се тичу организовања ученика на часу, као и потребу да се наставник стално усавршава. Знајући колико је темељна припрема и добра организација часа важна за реализацију циљева и задатака наставног процеса, као и у којој је мери константно стручно усавршавање наставника неопходно, може се закључити да ученици поједине аспетке наставе не могу да схвате и перципирају на прави начин, што је и разумљиво с обзиром на то да је процес њиховог образовања и даље у току. Поред тога, треба имати на уму да су предмет процењивања од стране ученика и наставника у овом раду биле улоге настаника физичког васпитања у наставном процесу, па је у складу са тим и очекивано да наставници имају позитивније мишљење о питањима која се тичу њихове струке у односу на ученике. Кроз школовање за позив за који су се определили, наставници развијају позитивне ставове и мишљења о својој струци. Ово у одређеној мери потврђује и истраживање Ковачевића (2013), које је имало за циљ да покаже како студенти четврте године Факултета спорта и физичког васпитања у Београду процењују компетенције наставника. Потребно је истаћи и занимљив податак до кога су дошли Аврамовић и Вујачић (2010), на основу испитивања мишљења наставника о томе како их виде ученици. Наиме, наставници сматрају да би их ученици веома позитивно оценили и то пре свега када је у питању комуникација са ученицима и припремљеност за наставу. Интересантно је да су управо ове две ставке, грубо гледано, у овом истраживању, вредноване као мање важне од стране ученика.

\section{ЗАКЉУЧАК}

На основу резултата добијених у овом истраживању, чији је основни циљ био да се испита мишљење ученика и наставника физичког васпитања о важности улога наставника у настави физичког васпитања, могуће је извести неколико закључака. Ученици и наставници све испитиване улоге наставника у настави физичког васпитања високо вреднују, при чему наставници свим улогама дају значајније вредности. И једни и други као најпотребнију наставничку улогу виде Улогу партнера у афективној интеракцији. Евидентна је сагласност међу ученицима посматрано према полу у вредновању наставничких улога, а једино се испољила разлика у погледу Улоге партнера у афективној интеракцији, коју ученице вреднују нешто више него ученици. Као најмање важну ученици и ученице видеУлогу регулатора социјалних односа у разреду као групи. У односу на врсту школе коју похађају, ученици се једино значајно разликују у опажању и вредновању Мотивационе улоге, којој мањи значај придају ученици Техничке школе. У односу на пол и радни стаж наставника нису се испољиле разлике у мишљењу о важности наставничких улога.

Наставник физичког васпитања треба да поседује стручна знања и вештине, као и одређене пожељне особине личности, које ће му омогућити да буде кључни фактор у процесу развоја ученика. Ово истраживање пружа увид у то које наставничке улоге ученици, али и сами наставници, сматрају важнијим од других. Оно може да представља путоказ и неку врсту водиље који ће указати на правац у коме би требало да буде усмерено даље стручно усавршавање наставника физичког васпитања. Будућа истраживања би требало да обухвате већи узорак ученика и наставника физичког васпитања, и испитивање фактора који играју значајну улогу у њиховом вредновању наставничких улога. 


\section{Напомена:}

Чланак представља резултат рада на пројектима: „Унапређивање квалитета и доступности образовања у процесима модернизације Србије“, број 47008 (2011-2014) и „Ефекти при-

\section{ЛИТЕРАТУРА}

1. Аврамовић, 3. \& Вујачић, М. (2010). Наставник између теорије и наставне праксе. Београд: Институт за педагошка истраживања.

2. Баковљев, М. (1988). Дидактика. Београд: Научна књига.

3. Бјекић, Д. (2000). Како ученици процењују остваривање улога наставника. Настава и васпитање 49(5), 707-724.

4. Вишњић, Д., Јовановић, А. \& Милетић, К. (2004). Теорија и методика физичког васпитања. Београд: Факултет спорта и физичког васпитања.

5. Вујачић, М. (2008). Како наставници виде сами себе. Настава и васпитање, 57(2), 230-241.

6. Даниловић, М. (2011). Наставник као узор, модел, идол, идеал, симбол, вредност, тј. мера савршеног и свестрано образованог човека. Зборник радова са 6. Међународног симпозијума Технологија, информатика и образовање за друштво учења и знања (стр. 3-25). Чачак: Технички факултет.

7. Darling-Hammond, L. (2006). Constructing 21st-century teacher education. Journal of teacher education, 57(3), 300-314.

8. Ивић, И., Пешикан, А. \& Антић, С. (2001). Активно учење. Београд: Институт за психологију.

9. Илић, Д., и Стевић, С. (1996). Мишљење седамнаестогодишњих ученица о професору физичког васпитања. Физичка култура 50(4), 306-311.

10. Илић, С. (2007). Мишљење ученика, родитеља и професора физичког васпитања о наставничким компетенцијама (Дипломски рад). Факултет спорта и физичког васпитања, Београд.

11. Јањушевић, М. (1967). Дидактика. Београд: Вук Караџић. мењене физичке активности на локомоторни, метаболички, психо-социјални и васпитни статус популације Републике Србије“ бр. III47015 (20112014), чију реализацију финансира Министарство просвете и науке Републике Србије

12. Ковачевић, И. (2013). Процена наставничких компетенција од стране студената Факултета спорта и физичког васпитања (Дипломски рад). Факултет спорта и физичког васпитања, Београд.

13. Кораћ, И. \& Сладојевић-Матић, J. (2014). Компетенције наставника - перспектива наставника и ученика. Зборник радова Учитељског факултета, Ужице 17(16), 235-248.

14. Крњајић, С. (2002). Социјални односи и образовање. Београд: Институт за педагошка истраживања; Вршац: Виша школа за образовање васпитача.

15. Lindgren, H. (1976). Educational Psychology in the Classroom. NewYork: JohnWiley\&SonsInc.

16. Лукач, Б. (2016). Испитивање мишљења ученика о улогама наставника физичког васпитања у наставном процесу (Мастер рад). Факултет спорта и физичког васпитања, Београд.

17. Петровић-Бјекић, Д. (2000). Успешност у настави и емпатија наставника. Психологија 33(3-4), 499-520.

18. Радовановић, Ђ. (1989). Ставови ученика према особинама наставника физичког васпитања. Физичка култура43(1-2), 53-58.

19. Радовановић, Ђ., Аруновић, Д., Мадић, Б. \& Вишњић, Д. (1993). Ставови ученика средњих школа у Србији према особинама наставника физичког васпитања. Физичка култура 47(12), 10-13.

20. Радовановић, И. (1994). Ставови ученика према особинама наставника физичког васпитања. Физичка култура 48(3), 223-228.

21. Рот, Н. (2003). Основи социјалне психологије. Београд: Завод за уџбенике и наставна средства. 
22. Shimon, J. M. (2011). Introduction to teaching physical education: Principles and strategies. Human Kinetics.

23. Соргић, Г. (1991). Пожељне и непожељне особине наставника физичког васпитања из ученичког угла (Дипломски рад). Факултет физичке културе, Нови Сад.

24. Tudor, I. (1993). Teacher roles in the learnercentred classroom. ELT journal, 47(1), 22-31.
25. Хавелка, Н. (2000). Ученик и наставник у образовном процесу. Београд: Завод за уџбенике и наставна средства.

26. Cox, A. \& Williams, L. (2008). The roles of perceived teacher support, motivational climate, and psychological need satisfaction in students' physical education motivation. Journal of sport and exercise psychology, 30(2), 222-239.

Примљен: 25. 07. 2018. Прихваћен: 15. 12. 2018. 